\title{
THE HIDDEN ROLE OF WOMEN IN MONITORING NINETEENTH- CENTURY AFRICAN WEATHER Instrumental Observations in Equatorial Guinea
}

by M. Cruz Gallego, Fernando Domínguez-Castro, José M. Vaquero, and Ricardo García-Herrera

Two Spanish women made important meteorological observations in 1875 on a small, solitary island in the Guinea gulf - an extraordinary labor never recognized until now.

$\mathrm{T}$ wo aspects of nineteenth-century meteorology are crucial to understanding the historical significance of some of earliest and best observations made in a data-sparse region of the world. First is the geographic lack of good quality daily and monthly historical weather measurements. A number of scientists have dedicated much effort over the last decades to recover, compile, and study a significant volume of early instrumental meteorological data

AfFiliations: Gallego-Departamento de Física, Universidad de Extremadura, Badajoz, Spain; Domínguez-CASTro AND GARCíAHerrera-Departamento Física de la Tierra II, Facultad de Ciencias Físicas, Universidad Complutense de Madrid, Madrid, Spain; VAQUERO-Departamento de Física, Universidad de Extremadura, Mérida, Spain

CORRESPONDING AUTHOR: M. C. Gallego, Departamento de Física, Facultad de Ciencias, Universidad de Extremadura, Avda. de Elvas s/n 0607I, Badajoz, Spain

E-mail:maricruz@unex.es

The abstract for this article can be found in this issue, following the table of contents.

DOI:10.1175/2010BAMS2807.I

In final form 2 August 2010

(C)20II American Meteorological Society
(Camuffo and Jones 2002). Many network-based meteorological stations were established in the late nineteenth century, partly in response to the deliberations of the Vienna Meteorological Congress held in 1873. However, large parts of Africa, Asia, South America, and Australia remained poorly represented (Jones and Bradley 1992). A second aspect of early historical meteorology-and even in more modern aspects of meteorology-is the role of woman in the atmospheric sciences, which has increased over time in both visibility and recognition (see Simpson and LeMone 1974; Simpson and Griffith 1982; LeMone and Waukau 1982; for an historical case, see Lewis 1995).

Given these two aspects of early historical meteorology, it is important to demonstrate the significance of two notable women, the Urquiola sisters, who created one of the oldest meteorological datasets known from the Guinea Gulf in Africa. Their contributions, including detailed weather measurements, some of them taken eight times per day, are now recognized as some of the first weather measurements made in central Africa.

These measurements were made with extraordinary dedication, recording a great amount of meteorological variables (temperature, humidity, 
rainfall, wind speed and direction, and cloud type and extension) with a high temporal resolution (eight times a day). Even the beginning and ending times of all the rainfall events were recorded (unless they occurred during the night). Such detailed meteorological data do not exist even today in the region. Although the instruments used might have had inaccuracies or the observation with some of them might not have been the most methodologically correct, comparison of the data obtained by the Urquiola sisters with current data from the nearest meteorological station shows many of the variables analyzed to be highly reliable.

Isabel and Juliana Urquiola traveled to Africa together with Isabel's husband, Manuel Iradier, who was an admirer of that continent and decided to explore it to achieve the dream of his life. While Iradier was exploring the mainland, the sisters remained on Little Elobey Island ("Elobey Pequeño"; Fig. 1) off present-day Equatorial Guinea's southwest coast, where one of their daily tasks was to record the meteorological variables in the observatory they had built. Despite their initial enthusiasm in helping to document weather conditions in the colony for Spain, the difficulty of life there-mainly because of a climate very different from that of their home city, Vitoria, in the north of Spain; the loss of their health with continuous episodes of fever; and the loneliness of the island-was damaging their spirit.

They found real difficulties. Iradier was conscious of the dangers that would stalk him and the women.
He expresses this when they go to Elobey for the first time:

I felt an immense emptiness in my heart and an enormous pressure in my brain. A voice, but a voice without timbre, without sound, told me to cross the seas again and fulfill your mission in the civilized countries in which you were born ... It is not you only. Together with you goes the fate of your companions, for have you not torn them from the bosom of their families where they lacked nothing to be happy? The fondness they profess for you is the bond that makes them follow you. You are going to deposit them on a wild island, you will surround them with all the amenities that are within your reach to provide them, but when you leave for the continent, do you know what dangers await them? ... What will be the fate of your companions? They will await your return for days and days, anxiously they will scan the African coast on the eastern horizon, in their crazed illusions they will see you on the crests of the blue mountains that they perceive in the distance in the mists of a torrid country ... they will see you coming in the fishermen's boats, they will dream that you are returning after you have finished your studies, but when the sun has passed many times over your home, when many tears have been shed in it, fervent prayers raised to heaven, some servant of yours saved from a disaster will announce to the beings you love that you died in the hands of savages, in the claws of wild beasts, or on the shores of some pestilential
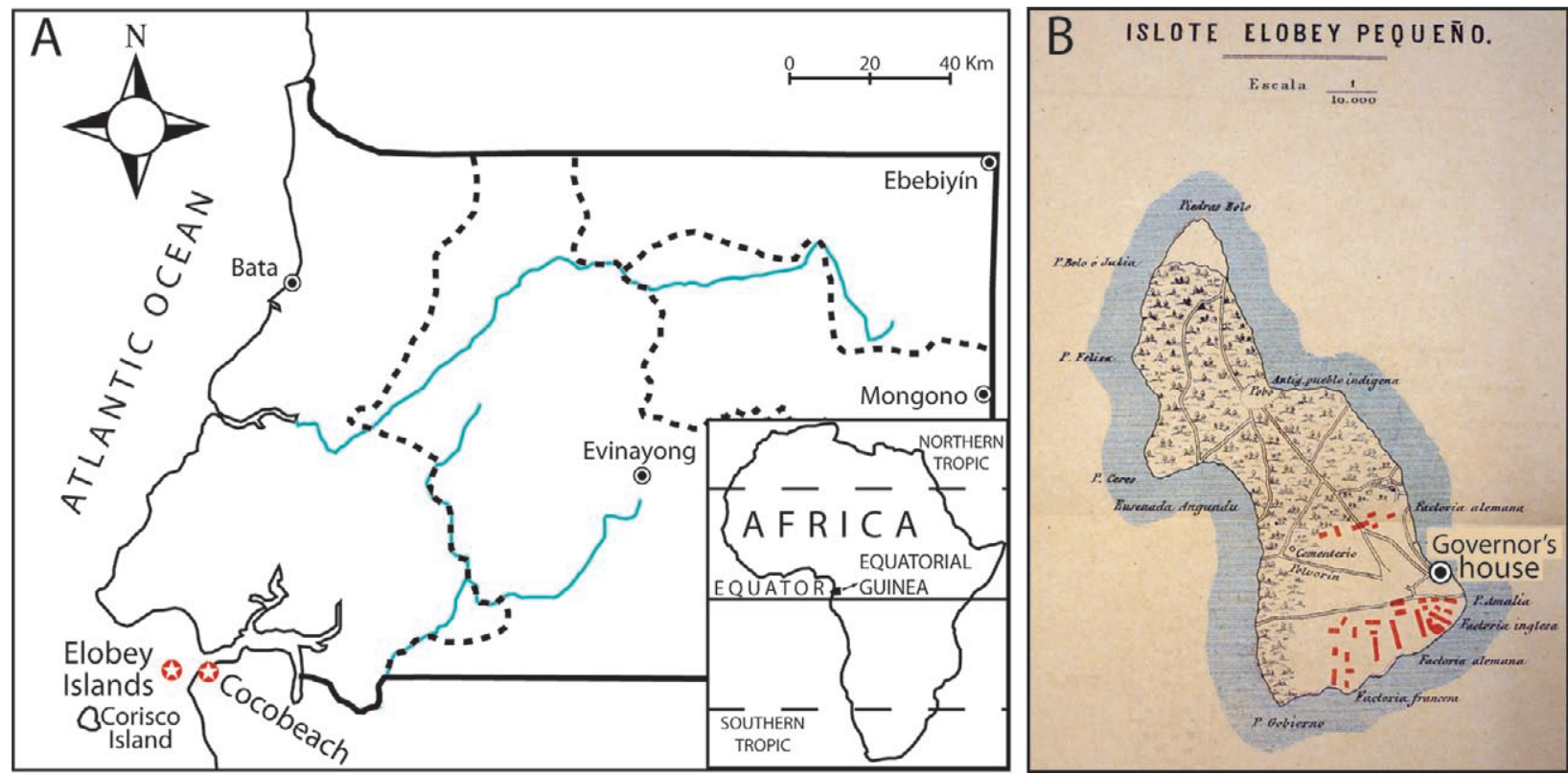

FIG. I. (a) Elobey Island location. (b) Little Elobey map (modified from Iradier 1887a,b). 
laguna ... They will return to their homes (the sisters) alone, and there in the town where you first opened your eyes to the light, they will mourn your loss; your name repeated on the lips of a child whom you never knew will serve as a constant torment to those who held you dear, and finally, your family, your friends and acquaintances, will give you the name bad husband and worse father for having followed a path that was not yours, for trying to fulfill a high mission that you mistakenly took for yours. Go back, for on your conscience will fall inexorable the weight of all the misfortunes that await you. (Iradier 1887a, 104-107)

Although none of the three perished, their task, though praiseworthy in its undertaking, ultimately caused both sisters as well as Iradier substantial health problems for the rest of their lives, which were compounded by the terrible suffering caused by the loss of a baby due to very high fevers.

HISTORICAL BACKGROUND. Equatorial Guinea was discovered for the Europeans by the Portuguese sailor Fernando Poo in 1471, and, as a result of its strategic trading location, this territory was used mainly for the slave trade. In 1778, Portugal passed this possession in the Guinean Gulf to Spain in exchange for territories in South America (the San Ildefonso and Pardo treaties). The African territory then continued under Spanish control until 1968.

During the nineteenth century, Spain did not pay much attention to Equatorial Guinea as a consequence of economic and political disturbances in Spain: the Spanish crown did not have funds to invest in the colony nor did it comprehend the nature of the benefits that it could obtain from this territory. In 1873, Governor Ignacio García Tudela recommended the abandonment of the colony due to its unhealthy climate ("much hotter and more humid than Spain, and a breeding ground for mosquitoes that carry malaria, ...") and scarce economic resources (Sierra Delage 2002). However, Manuel Iradier (July 1854-August 1911) decided to travel to the African colony with the objective of exploring it, studying the possibility to secure more territories for Spain, opening new routes to access the interior of the African continent, and gaining experience for his ultimate dream: crossing the African continent from south to north. Iradier showed an early interest in exploration. He founded "La Joven Exploradora" ("The Young Explorer") association and organized travels and explorations when he was only 16 years old. The association was originally based around Vitoria, capital of the northern Spanish province of Alava, and it promoted the collection of plants, animals, and minerals and the restoration of scientific instruments. However, the principal aim of the association was to organize the expedition to cross Africa.

In November 1874, the explorer married Isabel Urquiola. One month later, Iradier set out to travel to Equatorial Guinea; Isabel Urquiola decided to sail with him and join his modest expedition, funded by family and friends. Surprisingly, Isabel's younger sister Juliana also joined the expedition. They were all very young-Iradier and his wife were only 20 and Juliana was 18 - and they had no experience in traveling beyond their home province in Spain. Indeed, the Urquiola women were daughters of a baker with no formal education. However, Iradier showed an enduring passion for Africa, which served to partially compensate his lack of resources and institutional support.

One month after their wedding, the IradierUrquiola couple and Juliana were leaving Vitoria course to Africa. Their first stop was the Canary Islands, where they stayed a few months adapting to the tropical climate and testing the instruments for their scientific investigations. Finally, on 25 April 1875 , they embarked in a mail steamboat that would take them to Equatorial Guinea. During these days of crossing, Iradier had mixed feelings between the worry for the well being of his two companions and his passion for the exploration of the African continent. After 21 hard days of navigation, the three young explorers landed on Fernando Poo Island. There they visited the governor of the island, who tried to dissuade them from continuing their expedition because of the precarious situation of the islands due to the lack of means and infrastructure; the inhospitable nature of those lands for Europeans due to the hard climate so different from that to which they were accustomed; and the unusual situation of an expedition with two women, despite their adventurous and scientific spirit. Disregarding the governor's warnings, they continued the voyage and on 19 May 1875 arrived on Little Elobey Island, where they established their expedition base. The Urquiola sisters remained there while Iradier began his exploration of the continent.

Iradier described the Spanish possessions in their many aspects (geographical, meteorological, geological, zoological, botanical, social, etc.). When he returned to Spain in December 1877, he published some of his results in a series of articles (Iradier $1879 a, b)$, but these papers were only reports or sum- 
maries of his great work Africa: Viajes y Trabajos de la Asociación Eúskara la Exploradora (Africa: Travels and Works of the Eúskara Association of the Explorer), published in Vitoria in 1887. This book appeared in two volumes, showing the travel diary and results of Iradier's travels to Equatorial Guinea, "Exploration of the Muny Country 1875-1877" and "Acquisition of the Muny Country 1884." Of critical interest in this paper is the second chapter of the second volume, which contains the daily weather observations made by the Urquiola sisters. They are a sample of the European interest in the study of the climate of the colonies. The European governments wanted to learn about the climate of their territories and how it affected European health, what kind of agriculture was best for the new colonies, or where the best places were to establish their settlements. This generated a significant amount of documentation with a great potential in historical climatology

\begin{tabular}{|c|c|c|c|c|c|c|c|c|}
\hline \multirow[b]{2}{*}{ Pechas. } & \multicolumn{8}{|c|}{ OBSERVACIONES TERMOMFTRICAS. } \\
\hline & $\mathrm{B}$ h. m. & $12 \mathrm{~h} . \mathrm{m}$. & 3h.t. & Gh.t. & T. máx. & T. min. & T.media & $\begin{array}{l}\text { Orcila- } \\
\text { cion. } \\
\end{array}$ \\
\hline 1 & 26 & 30 & 31 & 28 & $31^{\circ} 00$ & $26^{\circ} 00$ & 2850 & $5^{6} 00$ \\
\hline 2 & 26 & 30 & 30 & 28 & $31^{\circ} 00$ & $26^{\circ} 00$ & 2850 & $5^{6} 00$ \\
\hline 3 & 26 & 31 & 315 & 29 & $31^{\circ} 50$ & $26^{\circ} 00$ & $28 \cdot 75$ & 5 \\
\hline 4 & 25 & 27 & 28 & 26 & $28^{\circ} 00$ & $25^{\circ} 00$ & 2650 & $3^{\circ} 00$ \\
\hline 5 & 24 & 27 & 28 & 26 & $28 \cdot 00$ & $24^{\prime} 00$ & $26^{\circ} 00$ & $4^{\prime} 00$ \\
\hline 6 & 25 & 30 & 31 & 27 & $31^{`} 00$ & $25^{i} 00$ & $28^{\circ} 00$ & $6^{\circ} 00$ \\
\hline 7 & 25 & 29 & 30 & 27 & $30^{\circ} 00$ & $25^{\prime} 00$ & 2750 & $5^{‘} 00$ \\
\hline 8 & 24 & 30 & 31 & 28 & $31^{\prime} 00$ & $24^{\circ} 00$ & 2750 & $7 \cdot 00$ \\
\hline 9 & 25 & 29 & 295 & 27 & 29550 & $25^{\circ} 00$ & $27 \cdot 25$ & 450 \\
\hline 10 & 25 & 29 & 30 & 28 & $30^{\prime} 00$ & $25^{6} 00$ & 2750 & $5^{\prime} 00$ \\
\hline 11 & 24 & 26 & 27 & 25 & $27 \cdot 00$ & $24^{\prime} 00$ & 2550 & $3^{\circ} 00$ \\
\hline 12 & 23 & 29 & $29 \cdot 5$ & 27 & 29450 & $23 \cdot 00$ & $26 \cdot 25$ & 650 \\
\hline 13 & 24 & 29 & 30 & 27 & $30^{\prime} 00$ & $24^{\prime} 00$ & $27^{\prime} 00$ & 6.00 \\
\hline 14 & 24 & 30 & 30 & 27 & $30<50$ & $24^{\prime} 00$ & $27 \cdot 25$ & 650 \\
\hline 15 & 25 & 30 & 31 & 28 & $31^{\prime} 00$ & $25^{\circ} 00$ & $28 \cdot 00$ & $6 \cdot 00$ \\
\hline 16 & 24 & 30 & 30 & 27 & $31 \cdot 50$ & $24^{\prime} 00$ & $27 \cdot 75$ & $7 \cdot 50$ \\
\hline 17 & 24 & 30 & 31 & 28 & $31^{\circ} 00$ & $24^{\prime} 00$ & $27 \cdot 50$ & $7 \cdot 00$ \\
\hline 18 & 25 & 30 & 31 & 28 & $31^{\circ} 00$ & $25^{6} 00$ & $28^{\circ} 00$ & 6.00 \\
\hline 19 & 24 & 30 & 31 & 28 & $31^{\prime} 00$ & $24^{\circ} 00$ & $27 \cdot 50$ & $7 \cdot 00$ \\
\hline 20 & 24 & 30 & 30 & 27 & $31^{\circ} 00$ & $24^{\circ} 00$ & 2750 & $7 \cdot 00$ \\
\hline 21 & 245 & 30 & 3055 & 28 & 3050 & 24.50 & 2750 & $6 \cdot 00$ \\
\hline 22 & 245 & 30 & 31 & 29 & $31^{\circ} 00$ & $24 \cdot 50$ & $27 \cdot 75$ & 650 \\
\hline 23 & 245 & 30 & 31 & $28 \cdot 5$ & $31^{\circ} 00$ & 2450 & $27 \cdot 75$ & $6 \cdot 50$ \\
\hline 24 & 25 & 30 & 31 & 28 & $31^{\circ} 00$ & $25^{\circ} 00$ & $28 \cdot 00$ & $6 \cdot 00$ \\
\hline 25 & $24 \cdot 5$ & 29 & 31 & 28 & $31^{\circ} 00$ & $24 \cdot 50$ & $27 \cdot 75$ & 6.50 \\
\hline 26 & 24 & 30 & 31 & 28 & $31^{\circ} 00$ & $24^{\circ} 00$ & $27 \cdot 50$ & $7 \cdot 00$ \\
\hline 27 & 24 & 30 & 31 & 28 & $31^{\circ} 00$ & $24^{\circ} 00$ & 27.50 & $7 \cdot 00$ \\
\hline 28 & 24 & 31 & 31 & 29 & $31^{\circ} 00$ & $24^{\circ} 00$ & $27 \cdot 50$ & $7 \cdot 00$ \\
\hline 29 & 24 & 29 & 31 & 29 & $31^{\prime} 00$ & $24^{\prime} 00$ & $27 \cdot 50$ & $7 \cdot 00$ \\
\hline 30 & 2355 & 30 & 305 & 28 & $31^{\prime} 00$ & 2350 & $27 \cdot 25$ & $7 \cdot 50$ \\
\hline 31 & 24 & 30 & 305 & 28 & $30^{\prime} 50$ & $\left|24^{\circ} 00\right|$ & $26 \cdot 25$ & 6550 \\
\hline & 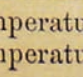 & & 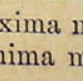 & 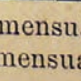 & . & . & & $\begin{array}{r}31 \\
.23 \\
\end{array}$ \\
\hline $\mathrm{T}$ & 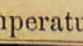 & & & & & Di & encia. & 8 \\
\hline
\end{tabular}

Fig. 2. Example of temperature table for December 1875 (Iradier 1887a,b).
(Browne 1799; Johnson 1827; Annesley 1829; Corbyn 1832; Boyle 1831).

\section{THE METEOROLOGICAL OBSERVATIONS.}

Meteorology was one of the most important topics for Iradier and the Urquiola sisters. More than 100 pages in his book (Iradier 1887a,b) were devoted to meteorological tables (Fig. 2) and personal accounts. The construction of the observatory was one of their first tasks when arriving on Little Elobey. Only 11 days after arrival (1 June 1875), Iradier and the Urquiola sisters were taking the first measurements in the observatory established in the governor's house $\left(0^{\circ} 59^{\prime} 46^{\prime \prime} \mathrm{N}, 9^{\circ} 32^{\prime} 14^{\prime \prime} \mathrm{E}\right)$ (Fig. 1b).

The observatory contained the following instruments: a centigrade thermometer, a maximum shade thermometer, a minimum thermometer, a Saussure hygrometer, an evaporation glass, a pluviometer, an anemometer, a photometer, an instrument to collect dew, a direct vision spectroscope, a prismatic telemeter, a Giró plumb-bob, a microscope, a quintant, a compass, and a pendulum. Unfortunately, other interesting instruments intended for the observatory such as a Fortin barometer, several thermometers, a chronometer, and a pedometer were lost in a fire during the voyage.

Some of the instruments were made by Iradier and, although their precision was not great, he observed in his book that "it was constructed by me, and while it is true that its measurements are not precise, they merit more credit than do mere personal appreciations" (Iradier 1887b, p. 26). The more interesting and accurate measurements were temperature, precipitation, wind (speed and direction), and relative humidity, so our focus is on those variables. The digitalized and checked data are available online (at http://salvasinobas.uvigo.es/index.php/eng/).

Temperature. The three thermometers were not calibrated with any official observatory thermometer, but Iradier made comparisons among them over a range from $22^{\circ}$ to $58^{\circ} \mathrm{C}$, and, in doing so, he detected an error of less than $0.5^{\circ} \mathrm{C}$. The instruments were located outdoors and shielded from the rain and sun by the roof of the house. According to Iradier $(1887 \mathrm{a}, \mathrm{b})$, readings were taken at $6,12,15$, and $18 \mathrm{~h}$ past midnight local time, but in Iradier (1879a) he wrote that the measurement hours were at $6,10,14$, and $18 \mathrm{~h}$; thus, there is some uncertainty in the actual recording times.

Precipitation. Iradier built the pluviometer, which consisted of a white cylindrical vessel made of zinc $(50 \mathrm{~cm}$ 
high and $27 \mathrm{~cm}$ in diameter), capped by a funnel. It was located in the middle of a small garden $1.22 \mathrm{~m}$ above the ground. Although the instrument was not of the highest quality, the observational procedures followed by the Urquiolas were faultless, recording the time of the beginning and the end of the precipitation and the amount of rainfall in millimeters as soon as a storm had ended. If the precipitation was during the night, the measurements were taken early in the morning. Two unusual observations, which were not very useful but show the interest and concern for the precision of the measurements, were also taken: 1) drop size (the first drop on a little polished board took on a spheroid shape and its diameter was measured with a microscope) and 2) rain strength (velocity of the drops) measured using a subjective scale from 1 to 5 , relative to the wind strength, where the first level was taken if the rain strength was similar to the wind strength, the second level was when the rain strength was 2 times the wind strength, and so on.

Winds. A 16-point compass was used to determine wind direction, and wind speed was measured with an anemometer also constructed by Iradier. The anemometer consisted of a vertical rod with four horizontal arms attached to four zinc hemispheres. Part of the vertical rod was supported by two connections to a wood box that contained a flap that made contact with a small spring of bamboo with each rotation, producing a perceptible noise that was counted and timed to determine wind speed. Both variables (force and direction) were taken at $6,8,10,12,14,16,18$, and $20 \mathrm{~h}$. The anemometer was transported to the "best places" (an open area, probably the beach) to measure the wind's intensity.

Relative humidity. Iradier built a Saussure hygrometer to measure the amount of moisture in the air. The instrument was located in a room in the observatory. In Iradier's words, "the instrument has been exposed inside the room to $0,50 \mathrm{~m}$ from a west window that always has remained opened" (Iradier 1887b, p. 26).

\section{ACKNOWLEDGMENT OF THE URQUIOLA} SISTERS' WEATHER OBSERVATIONS.

Iradier $(1887 a, b)$ does not explain who made each of the weather observations at Little Elobey, but he admits that "it was impossible that only one man with scarce resources should take all the astronomical, geological, zoological, botanical, mineralogical, ethnological, meteorological ... observations." Moreover, many times during the observational period, Iradier was on the continent exploring and it was impossible for him to take the measurements at Little Elobey observatory. However, at the end of a talk given on 25 May 1886 to the Royal Geographical Society of Spain, he declared the following concerning the meteorological observations:

Before finishing I must make a confession that I was determined to hide... If I in my first travels was busy exploring forest, rivers, climbing mountains and visiting tribes ... how could I observe the thermometric column, the udometer scale, the hygrometer pointer, the water evaporation, the plumb-bob oscillations, the winds and clouds directions and the storms? I did not take those observations. The credit goes to my partner who neither for the most powerful reasons nor the most prudent advices, nor the more affectionate entreaties could give up in her determination to stay with me. This partner was my wife. (Iradier 1886).

This is perhaps the only acknowledgement that Iradier made of his wife's work on Little Elobey Island while he was exploring the coast and continent. In his book, Iradier does not otherwise recognize the work of his wife. In fact, when he described the lives of his wife and sister in law on Little Elobey, he mentioned activities such as fishing, observing the daybreak and sunset, taking care of the garden, walking, and collecting beautiful butterflies but completely neglected to mention the laborious task of making numerous meteorological observations every day.

The Urquiolas' stay on Little Elobey was not as pleasant as Iradier's description of "butterfly collecting" above suggests. The equatorial African island was small, without drinkable water or any comforts, with a stressing climate of heat and humidity that was vastly different from their home city. From arrival on the island on 19 May 1875, the two women spent long periods awaiting the return of Iradier without receiving any news. In fact, even when Isabel was pregnant, the sisters endured up to three months without knowing anything of Iradier, who had fallen ill while exploring the northern bank of the Muni River. It is likely they therefore would have been constantly anxious because of the hard conditions and the lack of news. Indeed, they all succumbed to tropical fevers during the expedition and their health never recovered completely. Rightly, when their daughter Isabela was born, on 18 January 1876, they received a letter from the governor of Fernando Poo inviting them to return there. Wanting to distance themselves from the anxiety and health problems experienced on Little Elobey, they decided to accept the invitation, 
thinking that the baby would have a better life there. The first days in the city of Santa Isabel (present-day Malabo) were happy for the family. However, despite having more routine comforts, the climate was even more devastating for all of them, including their small daughter, who suffered continuous attacks of fever. On 28 November 1876, at just 15 months of age, little Isabela died from the fevers. Iradier reports it this way in his book:

Sixty-six bouts of fever I suffered in Santa Isabel, thirty-seven my wife, sixteen my sister-in-law, and fifteen my daughter born in Elobey [over a period of time from January 24 when they arrived in Santa Isabel to November 28 or so when their daughter dies]. My house was a hospital, and many times we were all bedridden in a single day. Joy had fled, silence came to rule completely, anæmia was advancing. I no longer saw animated physiognomies, joyful faces; the smiles had been replaced by melancholy ... death threatened us and we had to make a serious determination to avoid a fatal outcome ... All these sufferings were still little for I was about to suffer the cruellest torment to which a parent can be subjected. On 28 November 1876, my beloved Isabela, Elobeyan by birth, fell wounded by her last fever. All in vain, the fever's access became pernicious; those beautiful eyes closed forever. Death hovered within the bosom of the family, and to prevent further misfortunes I sent my loved ones who with so much self-denial had accompanied me to those climes to recover their failing health on the beautiful beaches of the Canary Islands. I was not left alone, the memory of my daughter pursued me everywhere. Before, I used to study routes, make maps of the courses of streams, collect insects, follow with interest the indications of my meteorological instruments. But after, I knew to walk only in one direction, to rest only at a single point. The grave of my Isabela, located at the foot of a gigantic mahogany, drew me with irresistible force. The memory of her drew me all day long. (Iradier 1887a, 344-346).

Both Isabel and Iradier were devastated. Indeed, in her heart, Isabel always accused Iradier of Isabela's death, and their relationship was distant until the end of their days (Morató 2004). After the tragedy, Isabel thought only of going back home to her family; her African adventure had ended.

\section{COMPARISON TO MODERN OBSERVA-}

TIONS. To check the quality of observations of the Urquiola sisters, we have compared them with the observations from the nearby modern meteorological station at Cocobeach $\left(1.00^{\circ} \mathrm{N}, 9.60^{\circ} \mathrm{E}\right)$-in present-day Gabon just across the estuary of the Muni River (Rio Muni) from Equatorial Guinea-for the period 1950-80 (Fig. 3). This reference period was selected because after 1980 the observatory started to accumulate missing values. Cocobeach data were taken from the National Oceanic and Atmospheric Administration (NOAA) Global Historical Climate Network (available online at www.ncdc.noaa.gov/oa/ climate/ghcn-daily/).

The temperature on Little Elobey is similar throughout the year, a consequence of the constant duration of day and night and the great humidity in the air. The daily minimum temperature occurs at approximately 5 a.m., whereas the maximum depends on the winds but usually occurs between noon and
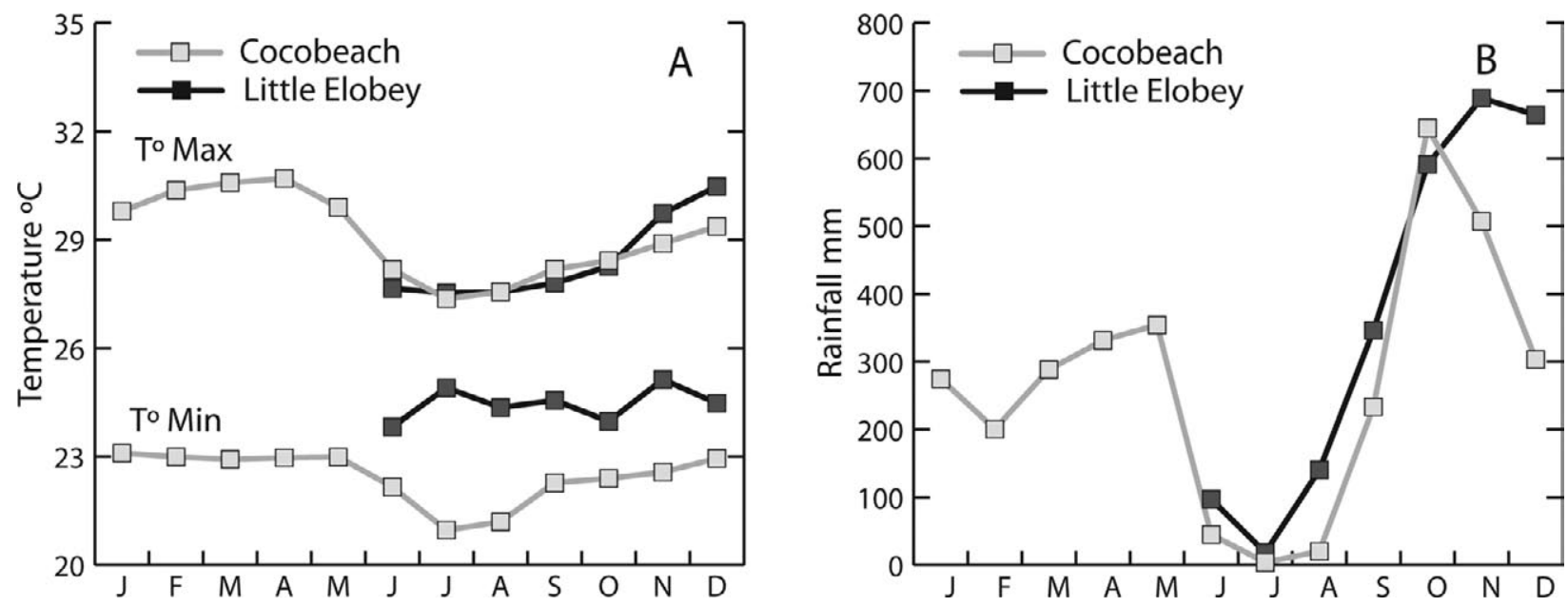

Fig. 3. (a) Maximum and minimum monthly mean temperature from Cocobeach (1950-80) and Little Elobey (June-December 1875). (b) Monthly rainfall for the same periods and stations. 


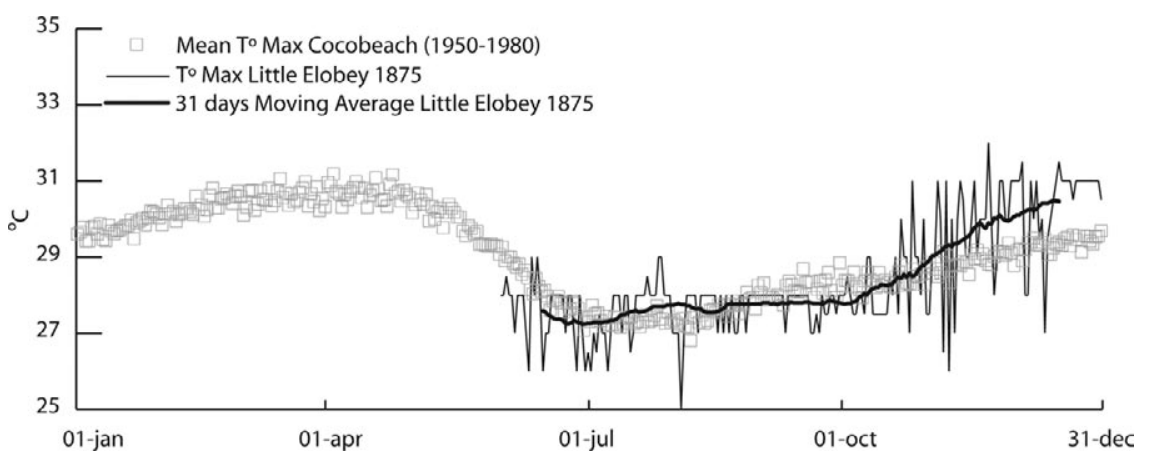

FIG. 4. Daily maximum temperature for Cocobeach (mean 1950-80) and for Little Elobey (1875).

4 p.m. The monthly-mean distributions of maximum and minimum temperature (Fig. 3a) show that the Little Elobey maximum temperatures recorded by the sisters are similar to those of Cocobeach but that minimum temperatures are $2.4^{\circ} \mathrm{C}$ higher than Cocobeach values and do not show the decrease during July and August. We offer three hypotheses to explain these differences: 1) the minimum thermometer may have suffered some instrumental problem; 2) the Cocobeach station's microclimatology may not match that of Little Elobey; and/or 3) because the Urquiola sisters did not possess a minimum thermometer, they merely recorded the lowest daily measurement as the minimum temperature. In fact, almost all of these values equal the measurements taken at $6 \mathrm{~h}$ (Fig. 2). This fact could explain the difference because the typical hour at which the minimum temperature occurred was one hour earlier. On the other hand, the maximum temperatures were correct because the Urquiola sisters had a true maximum thermometer.

Figure 4 shows the annual daily maximum temperature distribution from Cocobeach during the period $1950-80$ and the maximum temperature for Little Elobey during the observational period of 1875 . The 1875 record oscillates around the average, except for November and December, which show a difference of $+0.97^{\circ} \mathrm{C}$.

Figure $3 \mathrm{~b}$ shows the annual monthly-mean distribution of precipitation from Cocobeach (1950-80) and the record for 1875 . Remarkably, December shows precipitation almost 2 times higher in 1875 than the $30-y r$ average. The published table (Fig. 5) shows how only six rainstorms during December accumulated $443 \mathrm{~mm}$, $140 \mathrm{~mm}$ more than the December mean for the period 1950-80. Also the wind speed during December was unusually high, especially during the rainstorms on 11 and 26 December, with speeds in excess of $100 \mathrm{~km} \mathrm{~h}^{-1}$. In the original weather record, a value of $481 \mathrm{~mm}$ appears for 19 December, but checking it carefully we conclude that no important storm took place on this date. Taking into account that 1) this suspected storm does not appear in the tempest table of Iradier's book (Fig. 5) where the most important storms were listed and 2) other meteorological variables do not show the typical changes of a great tropical storm [i.e., relative humidity of $84.25 \%$ (mean for December 1875 is $87 \%$ ) or wind speed of $4 \mathrm{~km} \mathrm{~h}^{-1}$ (mean for December 1875 is $24.4 \mathrm{~km} \mathrm{~h}^{-1}$ )], we have rejected this record.

It is interesting to note how Iradier described some of these storms. For example, he wrote of the storm that took place on 11 December:

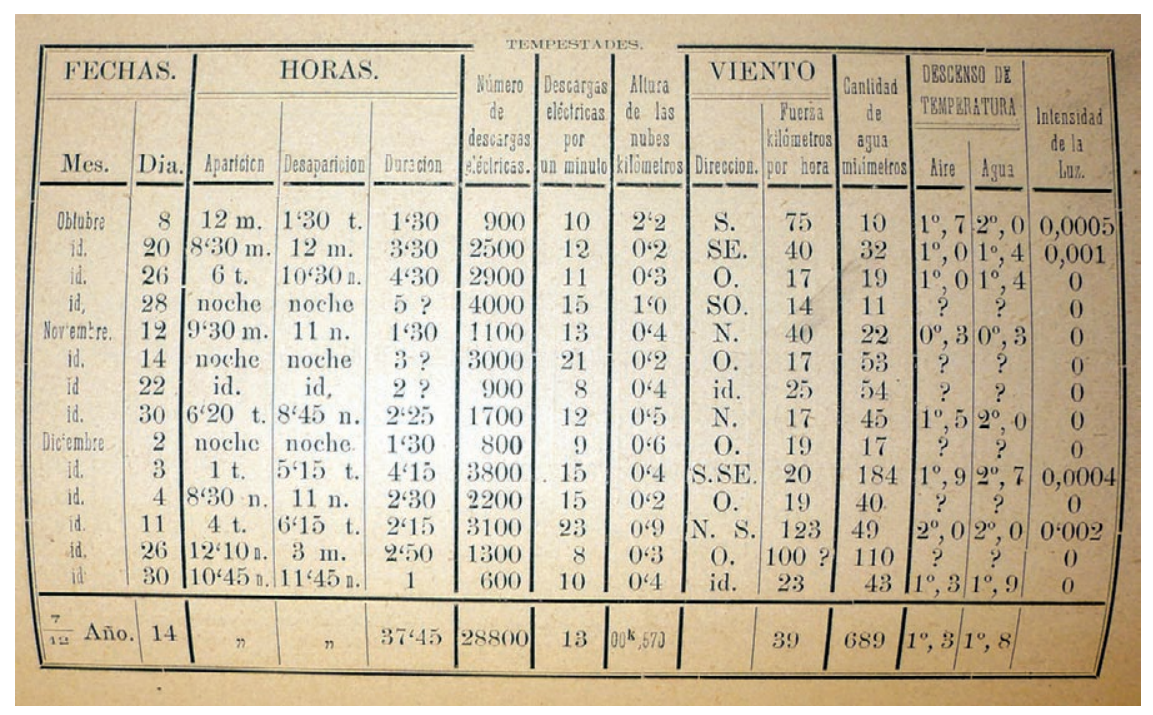

FIG. 5. Tempest table (Iradier I887b). Columns, from left to right, are date (month and day), hours (start, finish, and duration), total lightning, lightning per minute, cloud altitude, wind (direction and speed), rainfall $(\mathrm{mm})$, temperature decrease $\left({ }^{\circ} \mathrm{C}\right)$ (air and water), and light intensity. 
Today 11 December at 4 of the afternoon, a horrifying storm is declared. The strong wind of the north jumps to the south and became a hurricane. The Saussure hygrometer marks $99^{\circ}$ (sic). The thermometer fell to $23^{\circ}$. The plumb-bob and the compass undergo disturbances. The water goes remarkably cold. The rain that has fallen in a single event indicates in the rain gauge $0.49 \mathrm{~m}$ [error in Iradier 1879a, $0.049 \mathrm{~m}$ ]; two nimbus cross the sky at 900 feet (250 meters) above the ground, the dark, the lightning storms, the whistle of the wind and the roars of the sea, make the nature picture truly sublime. At 6 it has finished. Several huts have fallen and many boats have wrecked (Iradier 1887b, p. 335).

The sisters' meteorological record also shows unusual weather during the last months of 1875 , with November and December hotter and rainier than the observational average from 1950 to 1980 . Those precipitation events were associated with intense storms: for example, 3 December, when one sister collected $184 \mathrm{~mm}$ in $4 \mathrm{~h}$ and $15 \mathrm{~min}$, and 11 December, when the wind record was $120 \mathrm{~km} \mathrm{~h}^{-1}$ and $49 \mathrm{~mm}$ of rain fell in $2 \mathrm{~h}$ and $15 \mathrm{~min}$.

\section{OTHER EARLY METEOROLOGICAL} RECORDS FROM GUINEA GULF. In Equatorial Guinea, other observers recorded measurements of meteorological variables in the nineteenth century. The observations of these authors present many differences with those of the Urquiola sisters.
Sociohistorically, those of the sisters are the only ones made by women, and they were made in a far more hidden-away location and under more precarious circumstances than those made by the men in Santa Isabel, because this was a "civilized" city, as the capital was described by Iradier on arrival there after his stay at Elobey: "A new sun shone on the horizon of my life. I was in a civilized town: living among Spaniards; sleeping in a good bed; eating bread and drinking wine; in a word, I was leaving the region of savagery and entering civilization" (Iradier 1887a, p. 343). Meteorologically, the sisters' observations are far more precise, not just because of the wider range of observations they made but also because of their temporal resolution: they were making eight measurements daily, whereas in the best of cases the other observers were making three. These other observations are graphed in Fig. 6 and include the people in the following paragraphs

Julián Pellón y Rodríguez was employed as a Spanish public works commissioner in Fernando Poo from 1859 to 1863 . He wrote Memoria Descriptiva de la Colonia Española de Fernando Poo (Descriptive Memory from Fernando Poo Colony), probably the most complete manuscript about the colony. Unfortunately, this contribution was never published, and the manuscript is lost. Only its index is available in Pellón y Rodríguez (1854) and in Sociedad Geográfica de Madrid (1898a,b). A summary of the meteorological chapter (in the original chapter 4 with 156 pages) was published in Observatorio
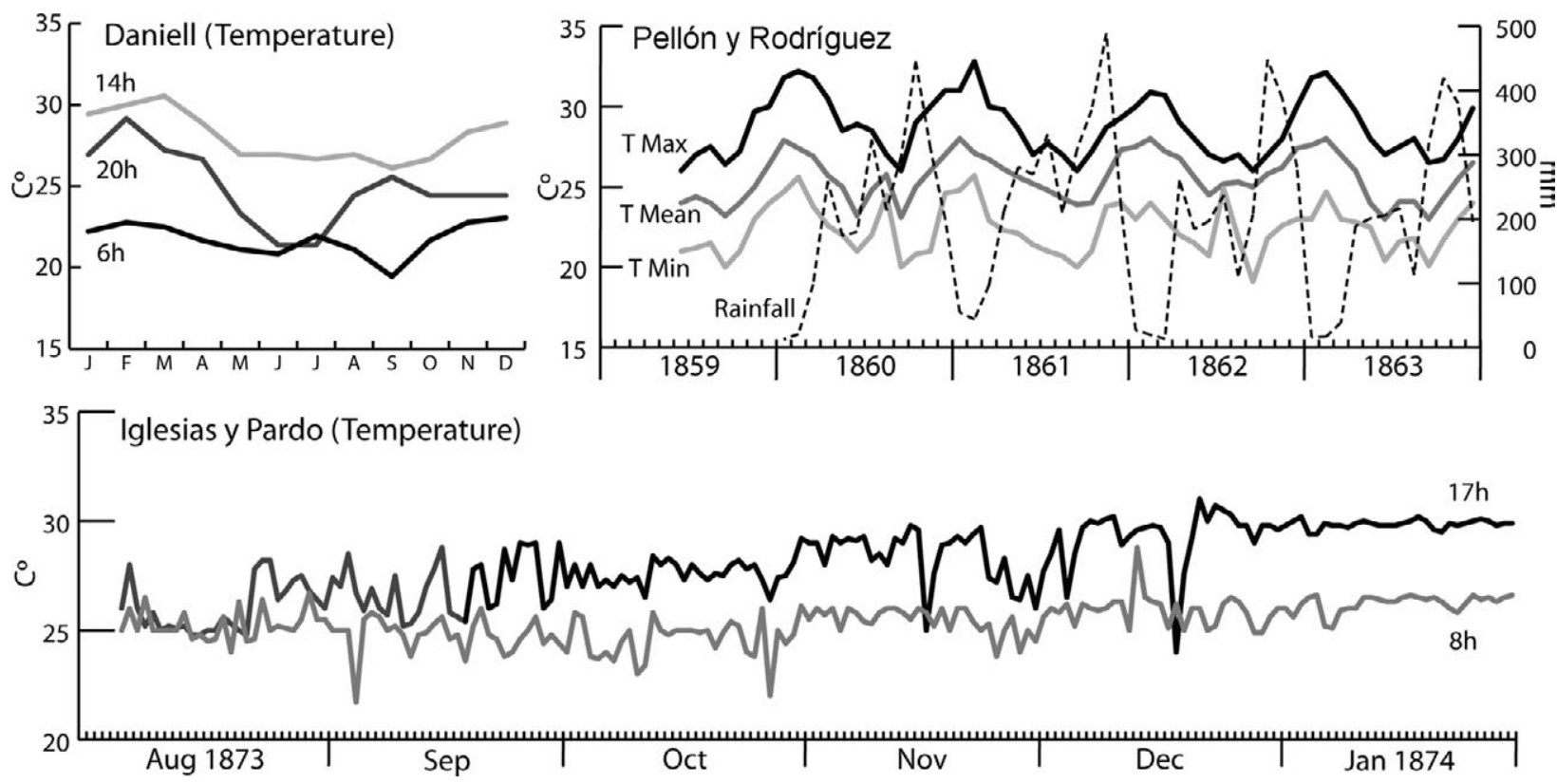

FIG. 6. Other observations from the Guinea Gulf. 
A stronómico de Madrid (1870) and in Iglesias y Pardo (1875), showing monthly means of minimum and maximum temperature and pressure (June 1859-December 1863), minimum and maximum Saussure hygrometer measurements (January 1860-December 1863),

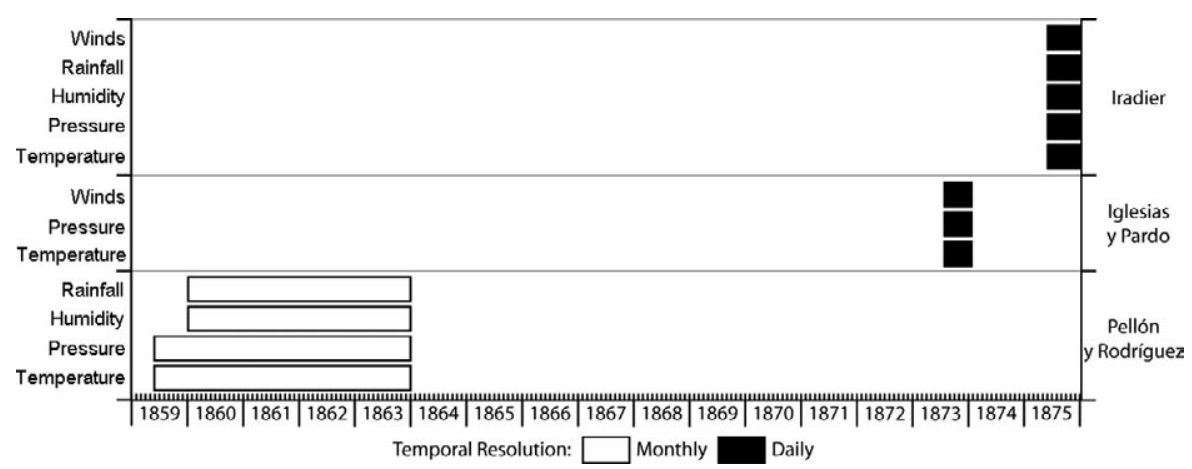

FIG. 7. Early instrumental series in Equatorial Guinea. and rainfall (January

1860-December 1863). Those measurements were taken in a small observatory located in his house (Calle del Armero, $14 ; 3^{\circ} 46^{\prime} \mathrm{N}, 12^{\circ} 28^{\prime} \mathrm{W}$ from Madrid meridian) almost in the center of Santa Isabel at $30 \mathrm{~m}$ above sea level.

Luis Iglesias y Pardo was a navy doctor who made observations at the navy station of the Guinean Gulf (Santa Isabel). His book (Iglesias y Pardo 1875) presents daily records from 6 August 1873 to 31 January 1874 of temperature (at 8 and $17 \mathrm{~h}$ ), pressure (at $8 \mathrm{~h}$ ), and winds (direction and speed) throughout the day.

William F. Daniell collected observations from different people [Colonel Nicholls and Mr. Becroft, both governors of Fernando Poo: Edward Nicholls (1829-30 and 1832-33) and John Becroft (1830-32 and 1833-54)] and, with his own measurements, calculated a general monthly picture using all of them, mixing measurements of different locations (the greatest portion were taken in Government House of Santa Isabel and onboard several vessels moored in the harbor) and years (the exact dates of the observations are unknown). On the other hand, these averages were the earliest observations, all of them taken in the first half of the nineteenth century. Daniell (1849) indicates that the temperature records were made at 6,14 , and $20 \mathrm{~h}$ each day. It is hard to assess the reliability of these data because there is not any information available on the period used to compute the averages or the precise location of the observatories.

Figure 7 shows the data available for Equatorial Guinea. The lack of information during many years, the different temporal resolution (monthly or daily), and the different locations of the observers make it impossible to produce a homogenous series from them. They remain useful, however, because of the singular events that occurred during these time frames. All of these records have been digitalized and are also available online (available at http://salvasinobas.uvigo.es/index.php/eng/).
CONCLUSIONS. With this paper, we are acknowledging the contribution to meteorology of two women in the Spanish colonies in Africa in the second half of the nineteenth century. We think that the Urquiola sisters, Isabel and Juliana, never received an appropriate acknowledgment of their extensive meteorological labors. Their observations and the descriptions herein emphasize the great contribution the sisters made in taking some of the first meteorological measurements in equatorial Africa, and we recognize their work measuring many different meteorological variables, some of them eight times per day, in an inhospitable area and despite mental and physical difficulties that culminated in the loss of Isabel and Iradier's young child. Although their meteorological record is short, it is one of the first measurements in Equatorial Guinea, it is unique for Little Elobey Island, and it was created by two sisters in a world where it was inconceivable that women could carry out such tasks.

ACKNOWLEDGMENTS. The authors are very grateful to D. Wheeler and the editor C. Cappella for helping us to improve the manuscript with his useful comments. This work was partialy supported by the Spanish Ministry of Environment (MMAMRM 200800050083542, SalváSinobas project), the Spanish Ministry of Education and Science (CGL2007-65891-C05-05) and the Junta de Extremadura-FEDER Funds (IB10077).

\section{REFERENCES}

Annesley, J., 1829: Sketches of the Most Prevalent Diseases of India. Thomas and George Underwood, $501 \mathrm{pp}$.

Boyle, T., 1831: A Practical Medico-Historical Account of the Western Coast of Africa. S. Highley, 423 pp.

Browne, W. G., 1799: Travels in Africa, Egypt, and Syria, from the Year 1792 to 1798. Cadell, $496 \mathrm{pp}$. 
Camuffo, D., and P. Jones, 2002: Improved Understanding of the Past Climatic Variability from Early Daily European Instrumental Sources. Kluwer Academic, 392 pp.

Corbyn, F., 1832: A Treatise on the Epidemic Cholera, As It Has Prevailed in India. Baptist Mission Press, 389 pp.

Daniell, W. F., 1849: Sketches of the Medical Topography and Native Diseases of the Gulf of Guinea, Western Africa. Highley, 200 pp.

Iglesias y Pardo, L., 1875: Observaciones Teórico-Prácticas Sobre las Fiebres Africanas de Fernando Poo: Precedida de Una Reseña Histórico-Geográfica de la Isla. Imprenta y Litograña de Taxonera, 137 pp.

Iradier, M., 1879a: Fragmentos de un diario de viajes de exploración en la zona de Corisco. Bol. R. Soc. Geogr. Madrid, 4, 253-356.

- , 1879b: Africa: Fragmentos de un Diario de Viajes de Exploración en la Zona de Corisco. Imprenta de Fortanet, $91 \mathrm{pp}$.

— 1886 : Exploración en territorios del golfo de Guinea: Discurso pronunciado por Don Manuel Iradier en la sesión de 25 de Mayo de 1886. Bol. R. Soc. Geogr. Madrid, 9, 25-36.

— , 1887a: Africa: Viajes y Trabajos de la Asociación Eúskara la Exploradora: Reconocimiento de la Zona Ecuatorial de Africa en las Costas de Occidente: Sus Montañas, Sus Ríos; Sus Habitantes; Clima, Producciones y Porvenir de Estos Países Tropicales. Posesiones Españolas en el Golfo de Guinea. Adquisición Para España de la Nueva Provincia del Muni. Vol. 1, Viuda e Hijos de Iturbe, 501 pp.

— , 1887b: Africa: Viajes y Trabajos de la Asociación Eúskara la Exploradora: Reconocimiento de la Zona Ecuatorial de Africa en las Costas de Occidente: Sus Montañas, Sus Ríos; Sus Habitantes; Clima, Producciones y Porvenir de Estos Países Tropicales. Posesiones Españolas en el Golfo de Guinea. Adquisición Para España de la Nueva Provincia del Muni. Vol. 2, Viuda e Hijos de Iturbe, 539 pp.

Johnson, J., 1827: The Influence of Tropical Climates on European Constitutions. Thomas \& George Underwood, 680 pp.
Jones, P. D., and R. S. Bradley, 1992: Climatic variations in the longest instrumental records. Climate since A.D. 1500, R. S. Bradley and P. D. Jones, Eds., Routledge, 679 pp.

LeMone, M. A., and P. L. Waukau, 1982: Women in meteorology. Bull. Amer. Meteor. Soc., 63, 1266-1276.

Lewis, J. M., 1995: Waves forecasters in World War II (with a brief survey of other women meteorologists in World War II). Bull. Amer. Meteor. Soc., 76, 2187-2202.

Morató, C., 2004: Las Reinas De Africa. Viajeras y Exploradoras por el Continente Negro. Circulo de Lectores, 345 pp.

Observatorio Astronómico de Madrid, 1870: Resumen de las observaciones efectuadas en la estación de Fernando Poo. Resumen de las Observaciones Meteorológicas Efectuadas en la Península Desde el 1 de Diciembre de 1867 á 30 Noviembre de 1868. Imprenta de Miguel Ginesta, 403-428.

Pellón y Rodríguez, J., 1854: Memoria Descriptiva de la Colonia Española de Fernando Poo y Sus Dependencias: Precedida de Una Reseña General Sobre el Golfo de Guinea. José Morales y Rodríguez, 30 pp.

Sierra Delage, M., 2002: Expediciones Españolas en África, via Siglo XIX. Ciencia y Memoria de Africa : Actas de las III Jornadas Sobre "Expediciones Científicas y Africanismo Español 1898-1998”, A. R. Díez Torre, Ed., Ateneo de Madrid, 317-328.

Simpson, J., and M. LeMone, 1974: Women in meteorology. Bull. Amer. Meteor. Soc., 55, 122-131.

_ , and C. Griffith, 1982: Management opportunities for women meteorologists. Bull. Amer. Meteor. Soc., 63, 167-169.

Sociedad Geográfica de Madrid, 1898a: La Guinea Española, Descripción general de Fernando Póo y sus dependencias, Índice de una obra inédita. Rev. Geogr. Colon. Mercantil, 10, 188-192.

— 1898 b: Descripción general de Fernando Poo y sus dependencias, Índice de una obra inédita (continuacion). Rev. Geogr. Colon. Mercantil, 11, 203-208. 